\title{
Design Men's Bag for Starter Kit in a New Normal Life During the Covid-19 Pandemic Using Doyo Weaving and Tumpar Embroidery
}

\author{
Dwi Cahyadi ${ }^{1,{ }^{*}}$ Etwin Fibrianie Soeprpato ${ }^{1}$ Andi Farid Hidayanto ${ }^{1}$ Ditha Nizaora ${ }^{1}$ \\ Hidayat Hidayat ${ }^{2}$ Erwinsyah $^{3}$ Sukmawati $^{4}$
}

\author{
${ }^{1}$ Design Department, Politeknik Negeri Samarinda, 75136, Indonesia \\ ${ }^{2}$ Mechanical Department, Politeknik Negeri Samarinda, 75136, Indonesia \\ ${ }^{3}$ Departement of Industry, Trade and Cooperatives East Kalimantan Provine, Ministry of Industry, 75121, Indonesia \\ ${ }^{4}$ Education Quality Assurance Institution East Kalimantan Province, Ministry of Education and Culture, 75136, \\ Indonesia \\ *Corresponding author. Email: dwicahyadi@polnes.ac.id
}

\begin{abstract}
Home industry handicraft products continue to survive in the current Covid-19 pandemic conditions. One way to survive in this condition is to innovate products to increase profits. This innovation can be made through the use of existing raw materials to produce products that are different from before. Doyo weaving is a typical Dayak woven cloth made from doyo plant fibers whose habitat is widely found in East Kalimantan Province, Indonesia. Doyo weaving can be combined with traditional regional embroidery, namely tumpar embroidery. This embroidery has an interesting characteristic in terms of the motifs that characterize the regional culture. The use of doyo weaving and tumpar embroidery is often used in handicraft products and women's fashion products. To help overcome this problem so that sales of doyo handicraft products and Tumpar embroidery continue to produce, it is necessary to design a men's bag product for a starter kit in facing a new normal life according to the government's recommendation during the Covid-19 pandemic. This bag will use doyo weaving and tumpar embroidery as the material for the bag. The purpose of this research is to design a new product by applying doyo weaving and tumpar embroidery on a men's bag as a container for the starter kit. The method used in this research is the Nigel Cross product development method. Initial data were collected through a questionnaire from 50 male respondents as a basis for product development. The results of this research are men's bag products made from doyo woven and tumpar embroidery which can be used for formal or casual events.
\end{abstract}

Keywords: Men's Bag, Starter Kit, New Normal Life, Doyo Weaving, Sulam Tumpar.

\section{INTRODUCTION}

Home industry handicraft products continue to experience a decline in sales amid the current Covid-19 pandemic conditions. The existence of a government health protocol that recommends keeping your distance and avoiding crowds of people in one place has led to a decrease in the number of human visits to the tourism sector. The decline in the tourism sector has a direct impact on the sales of handicraft products from home industries due to the lack of visitors. The solution for the home industry to survive in this condition is to innovate craft products to maintain product sales figures. This innovation can be done through product development that is different from before but still uses the same raw materials. One of the handicrafts affected by the Covid19 pandemic is doyo weaving. Doyo weaving is a typical weaving made by Dayak tribes in Kalimantan from doyo plant fiber. This plant is often found in West Kutai district, East Kalimantan Province, Indonesia. Doyo has been used by the Dayak tribe in various traditional and daily activities as a handicraft and fashion product. The use of doyo is now often combined with additional accessories, one of which is tumpar embroidery. Tumpar embroidery is embroidery like in general, the difference is that this embroidery has an interesting characteristic in terms of its motifs which characterize the culture of the Dayak tribe in East Kalimantan. The combination of 
doyo and tumpar embroidery is often used in handicrafts and fashion products, especially for women.

To overcome this problem, the sales of doyo woven handicraft products and tumpar embroidery from East Kalimantan continue to increase, new product designs are needed. The product as a new innovation is a men's bag design for starter kit needs that can be used in a new normal life as recommended by the government in carrying out activities during the Covid-19 pandemic. The material of this bag uses doyo weaving and tumpar embroidery as ornaments so that the production from the home industry continues to produce. The purpose of this research is to design a new product by applying doyo weaving and tumpar embroidery on a men's bag as a container for the starter kit. The positive contribution of this research is to help regional handicraft products that are of interest to all genders and indirectly open new markets in the midst of the current Covid-19 pandemic conditions.

\subsection{Literature Review}

\subsubsection{Handicraft Production During The Covid- 19 Pandemic}

The development of the home industry in Indonesia in the field of product and service sales has decreased since the Covid-19 virus pandemic this year. This virus is categorized as a virus that attacks the respiratory tract and can be transmitted from human to human [1]. The impact of human-to-human transmission has decreased the income of the tourism sector. The declining tourism sector has a direct impact on sales of handicraft products because the fewer visitors. The impact of lack of visitors to the home industry will also have an impact on product absorption, availability of raw materials, and the product distribution process [2].

Some of the recommended survival strategies for products from home industries to be able to maintain their business by improving product quality and adding types of services to create customer loyalty. Product quality improvement can be done by modifying existing products and increasing target customers.

\subsubsection{Doyo Weaving and Sulam Tumpar}

Doyo weaving is a type of tie weaving made from doyo leaf fiber (Curliglia latifolia). Doyo is a type of pandanus plant that has strong fibers and grows wild in the interior of Kalimantan, including in the village of Tanjung Isuy, Jempang, West Kutai [3]. Doyo weaving is not only famous because it uses natural fiber as a base, but also because it is colored with natural dyes [4].

Doyo weaving is commonly used in handicraft products and fashion products. This weaving can be given a color pattern from natural materials and formed with certain motifs [5]. In figure 1 is an example of doyo weaving with colors and patterns. The doyo weaving that is not colored tends to be light brown. In Figure 2 is an example of doyo weaving that is not dyed. Doyo weaving which is not given a color can be used as a basic material for typical embroidery from East Kalimantan which is commonly referred to tumpar or sulam tumpar.

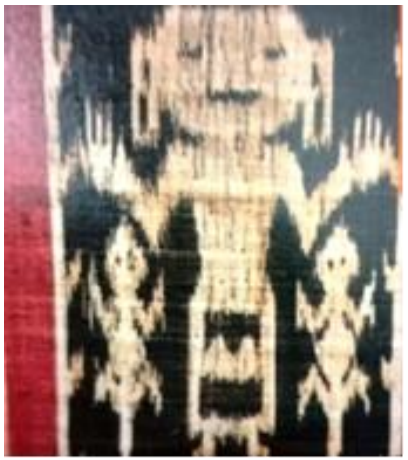

Figure 1 Doyo weaving with colors and patterns

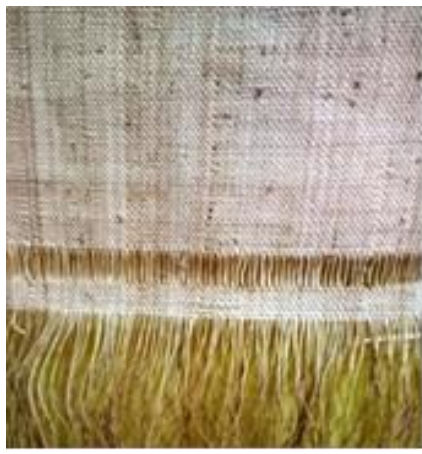

Figure 2 Doyo weaving with no colors

Sulam tumpar, in principle, is the same as embroidery in general. This embroidery can be applied on other fabrics or materials such as doyo weaving with sewing needles and woolen threads. Sulam tumpar has a motif based on the flora and fauna of the local community. This embroidery is applied to beautify products such as bags, necklaces and clothes commonly used by women [6]. Figure 3 shows an example of the use of doyo weaving and two partridge motifs of sparrow embroidery on woman's handbag [7].

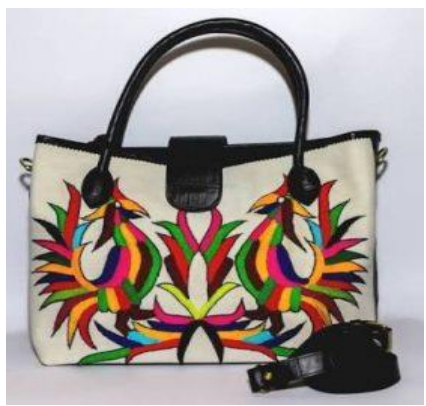

Figure 3 The application of doyo weaving and sulam tumpar on a woman's bag 
Embroidery motifs tend to be feminine, because the thread colors used tend to have a striking color [8]. This is because these colors are commonly used by the Dayak tribe in East Kalimantan in some of their products as cultural heritage from their ancestors. Culture is a lifestyle that has been developed from generation to generation by a group of people.

\subsubsection{Kansei Engineering}

Kansei engineering, based on Japanese philosophy and culture, is based on a non-reductionist point of view. Attention to the relationship between humans and the world or the environment can lead to dynamism, and more opportunities for creation [9] [10]. Kansei engineering (KE) can investigate the emotional needs of users and determine the relationship between emotions and features of a product [11]. Kansei can be used to develop new product designs [12]. In engineering kensai the role of the most important is as input in the development of a product [13]. Kansei engineering focuses on sensitivity, feelings and emotions [14] [15] [16]. Kansei can also be defined as a high function of the brain associated with emotions, sensitivity, feelings, experiences [17].

\subsubsection{Product Design Development}

In designing and developing a product, many methods can be used, one of which is the Nigel Cross method. The Nigel Cross method can be oriented to product development as a result of input from consumers [18]. In general, there are four stages in this method. These stages are the stages of exploration, generation, evaluation and communication [19]. To help design and develop products, what is done by knowing the needs of consumers. Consumer needs can be searched through observation and questionnaire results on consumer needs for a product [20] [21]. In designing a product, many factors must be considered. These factors include the form and system factors. Form will describe bag space, while the system will discuss systems such as connections, open and close operations on bag products. Material and color factors also affect the design of a product. Suitable materials will be related to the comfort and aesthetics of the materials to be used in a product.

The color factor can affect the marketing of a product because the color can evoke a mood that leads the buying interest from consumers. According to research, in marketing a product, men prefer darker colors [22]. The configuration of the bag product is also very important as a factor that can affect human activities in interacting with the product. Configuration related to the placement of components related to product activities and functions. Another important factor is ergonomics. In designing a product, ergonomics are needed to provide solutions in product use, so it is comfortable and safe to use [23][24].
Anthropometric factor is a determinant of product dimensions to make it more ergonomic [25]. Anthropometry plays a role in providing product sizes according to the ethnicity in which the product will be marketed. By utilizing precise anthropometric data, the dimensions of the product being designed will not interfere with the comfort of the product itself [26].

\section{METHOD}

This study applies the product development method of Nigel Cross. The product development method consists of four main steps which will be combined with the kansei engineering method and as shown in the Figure 4:

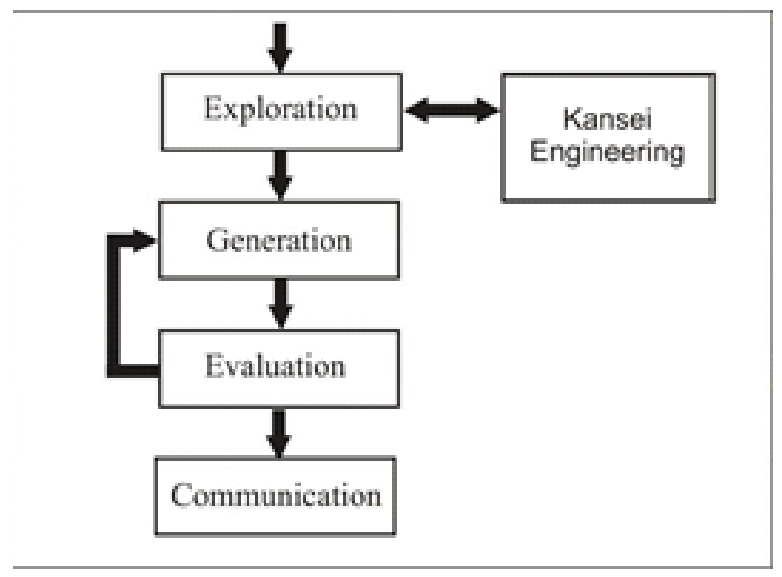

Figure 4 Nigel cross method

The exploration stage is carried out by the product identification process by taking the data from questionnaires obtained from consumers. Generation stage is the process of adjusting the results of consumer desires with technical matters related to the product development team. The next step in the evaluation stage is the process by which product design and development is carried out. The final stage is communication where in this activity the final design of the man's bag product made from doyo weaving and sulam tumpar.

\section{RESULT AND DISCUSSION}

The design development of man's bag product with the addition of doyo weaving and sulam tumpar in this study through the stages that exist in the product development model of Nigel Cross as follows:

\subsection{Exploration}

At this stage, the initial research process is carried out to seek input from consumers who will wear man's bag products with a combination of materials from doyo weaving and typical embroidery from the Dayak tribe in East Kalimantan. Input from consumers in the form of questionnaires distributed to 50 male gender respondents aged 20 to 50 years. From the results of the questionnaire 
and kansei engineering method, it is obtained the main factors that can be used in designing this man's bag product. The design factors for the man's bag product are:

a. Material and color factors, material are factors to determine the material that will be used on the product. The color factor is needed to determine the appropriate color to be applied to man's bag products.

b. Form and systems, are factors related to the design of the form of space that is adjusted to the design concept of the product to be made. While the system factor is to find out what systems the product needs in order to function properly without reducing the comfort of men's bag products.

c. Activities and configuration are factors related to the activity of using the product when it is used so that the usage needs of the product will be obtained. The configuration factor is a factor in obtaining the arrangement of the existing component layouts including the doyo weaving position and the sulam tumpar motif on man's bag.

d. Ergonomics and anthropometry, are factors that affect the comfort, convenience and appropriate size of the user for the designed man's bag product.

\subsection{Generation and Evaluation}

This stage was carried out by the process of adjusting the results of the questionnaire with the technical requirements of designing a men's bag product by displaying doyo weaving and tumpar embroidery. This adjustment resulted in several things that were a response to the factors that existed at the exploration stage, namely:

\subsubsection{Material and Color Factors}

In this factor, the material used is a combination of ingredients from natural products. The main material is leather cow that has been processed. The skin color chosen is a dark color, which is dark brown according to input from consumers. Additional materials that will be highlighted in the man's bag products with the nuances of the Dayak tribe are doyo weaving and tumpar embroidery.

The doyo weaving used is non-colored woven. This weaving will later become the base for the motif of the Dayak tribe, namely the tumpar embroidery. The sulam tumpar which is knitted on the doyo woven cloth has a motif in the form of a crane as a masculine symbol as shown in Figure 5. The chosen crane is the Egretta garzetta type, which can be found mostly in swamps and in several places along river banks and in mangrove areas [27].

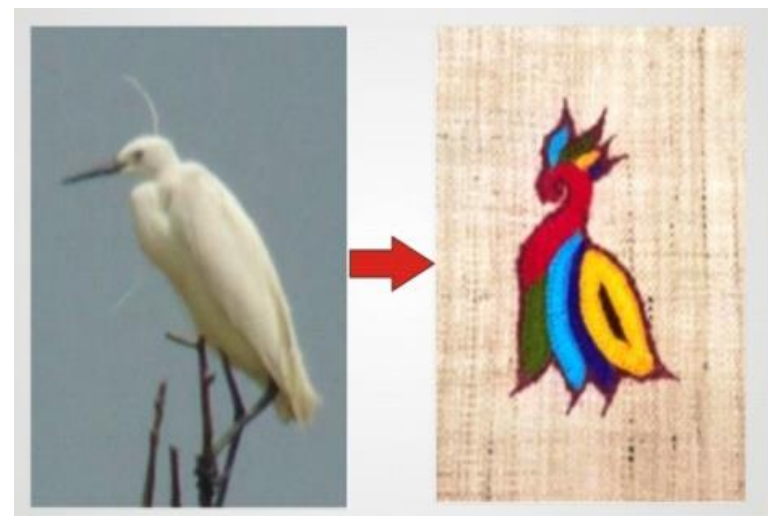

Figure 5 The shape of a crane for embroidery motif

\subsubsection{Form and systems}

The shape of this product design is in the form of a box with a contemporary design style. This forms was chosen based on input from consumers who wanted more of this man's bag to be used in casual and formal activities. The main connection system applied to this man's bag is the stitching system as a binder between the materials that make up the bag model. For the closing and opening system for the inside of the bag, using a zipper and a magnetic button system for closing and opening the outside of the bag.

The connection system between the strap and the bag body uses a stainless steel bag hook system. This man's bag can be modified into two types, namely a sling bag and a handbag while still displaying the doyo weaving and its sulam tumpar motif. The development of this modified bag product was developed by researchers to meet the desires of consumers who want a men's bag that can be used in casual and formal activities.

\subsubsection{Activity and Configuration}

This factor will analyze activities related to product use. In order to support user activities, the product needs the highlighting the doyo weaving and sulam tumpar. The bag product consists of a main area and an additional area for storage. In addition, the doyo weaving material and the image motif of the sulam tunpar are specially displayed on the bag design. The need for these products is in the form of slots or areas that are used to store starter kit for new normal life in pandemic covid-19. A starter kit is recommended equipment that must be carried in the face of a new life during the Covid-19 pandemic. As for the starter kits, according to suggestions from the Indonesian Ministry of Health, are masks, hand sanitizers, launch boxes, prayer kits, wet and dry wipes and drink bottles, as shown in the Figure 6 . 


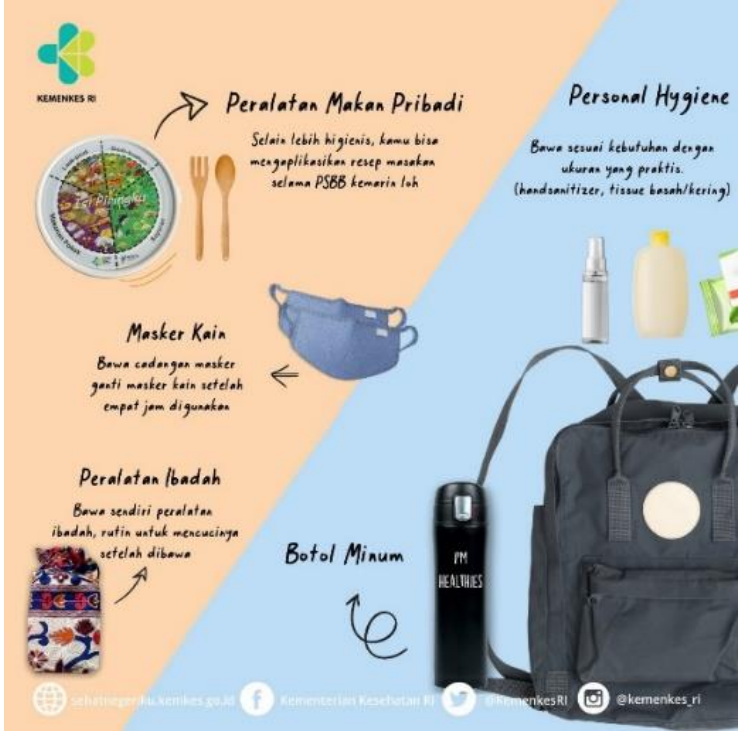

Figure 6 Recommendation starter kit from the Indonesian Ministry of Health

\subsubsection{Ergonomics and Anthropometry}

Factors that affect the comfort, convenience and appropriate size of the user for the product being designed. Ergonomic factors prioritize comfort and safety when using the product. The ergonomic factor looks at the use of the type of material in the product that is comfortable and safe to use. In addition, ergonomics also plays a role in determining the ease of use of the bag and the ease with which it is transformed from a handheld bag to a sling bag or vice versa. The anthropometric factor emphasizes the dimensions of the product that must be adjusted to its users, namely adult men from Asian countries as seen in figure 8. Anthropometric data used is anthropometric data of adult male Asian ethnic groups. To measure the length of the bag used anthropometric data from the dimensions of the men's shoulder width using 95 percentile.

The dimension of this shoulder width is $470 \mathrm{~mm}$, which is the basis for the maximum length value for men's bag products. Thus, the length of the men's bag to be made is $250 \mathrm{~mm}$ because it is still within the tolerance value. To determine the width of the bag, the body dimensions of an adult male's hand length are 95 percentile with a value of $195 \mathrm{~mm}$ as the maximum width of the bag. For bag design in this study, the width of the bag used is $150 \mathrm{~mm}$. To measure the length of the base of the bag, a man's hand width is 95 percentile with a maximum value of $90 \mathrm{~mm}$, and the design of this men's bag product uses a size of $80 \mathrm{~mm}$. In figure 7 shows the anthropometry used to determine the size of the bag product.
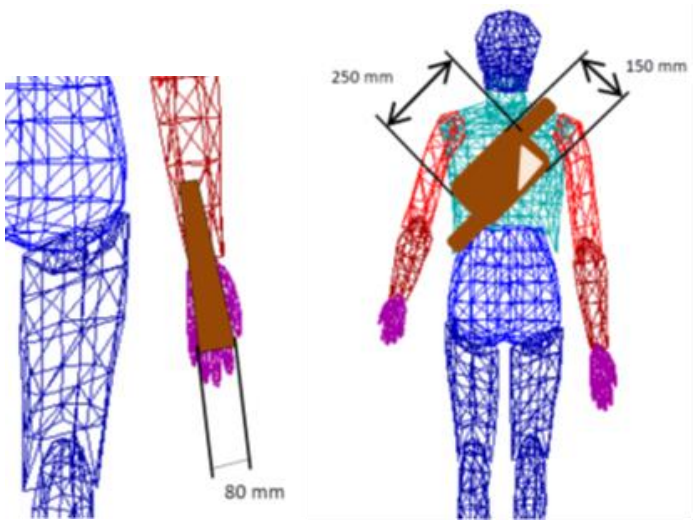

Figure 7 Anthropometry to determine product size

\subsection{Communication}

At this communication stage, product design and development reaches the final stage which is the conclusion of the generation and evaluation stages. The final result of a man's bag product that accentuates the elements of Dayak culture in East Kalimantan by adding doyo weaving and sulam tumpar will look like the image below. The product innovation proposed in this research in the form of the use of doyo weaving and sulam tumparon man's bag is expected to add new target markets. Figure 8 below represent the final design of this study. The figure 9 is the final design in the form of a men's bag prototype using doyo weaving and tumpar embroidery containing a starter kit for a normal life according to the recommendation from the Indonesian Ministry of Health.

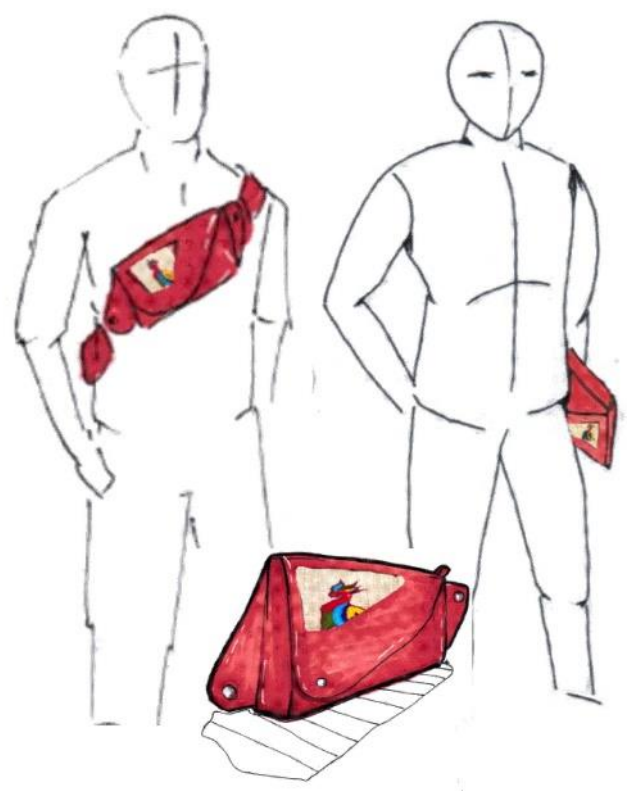

Figure 8 Men's bag design model 


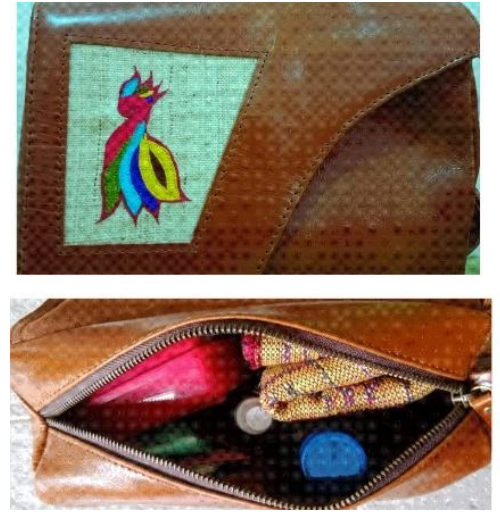

\section{STARTER KIT}

Masks
Bottle
Prayer Mat
Fork \& Spoon
Launch Box
Hand sanitizer
Wet and dry wipes

Figure 9 Men's bag as a starter kit container for a new normal life

\section{CONCLUSION}

The contribution of this research is to apply home industry products in the form of doyo weaving and tumpar embroidery on men's bag products so that the products from the home industry can continue to produce and develop through product innovation. This designed men's bag functions as a starter kit in carrying men's equipment and needs during this Covid-19 pandemic. The handicraft product innovation was carried out by making men's bag products for the needs of the starter kit recommended by the Indonesian Ministry of Health in facing a new normal life during the Covid-19 pandemic. The bag design uses traditional materials from doyo weaving and tumpar embroidery. Thus doyo weaving and tumpar embroidery will always exist and have customer loyalty in handicraft products in the conditions of the Covid-19 pandemic by transforming and adding new markets for male consumers.

\section{ACKNOWLEDGMENTS}

We sincerely thank the Ministry of Research and Technology Indonesia and the Politeknik Negeri Samarinda for funding this research. In addition, we would like to thank Dekranasda Kaltim and Pokant Takaq for the data obtained to assist us in this study.

\section{REFERENCES}

[1] Muhammad Adnan Shereen, Suliman Khan, Abeer Kazmi, Nadia Bashir, and Rabeea Siddique, "COVID-19 infection: Origin, transmission, and characteristics of human coronaviruses", Journal of Advanced Research, Vol. 24, 91-98, 2020.

[2] Rais Agil Bahtiar and Juli Panglima Saragih, "Dampak Covid-19 Terhadap Perlambatan Ekonomi Sektor UMKM”, Kajian Singkat Terhadap Isu Aktual dan Strategis, Vol. XII, No. 6/II, 2020.

[3] Mita Purbasari and Anita Rahardja, "Warna Tenun Doyo Sebagai Expresi Masyarakatnya (Tanjung
Isuy-Kutai Barat)", Dimensi, Vol.14, No.2, February 2018.

[4] Dana Kurnia Syabana, Yudi Satria, and Retno Widiastuti, "Aplikasi Zat Warna Alam Pada Tenun Serat Doyo Untuk Produk Kerajinan”, Dinamika Kerajinan dan Batik, Vol. 30, No. 1, June, 2013.

[5] ..., Buku Profil Serat Doyo, Disperindagkop dan UMKM, Provinsi Kaltim, 2014.

[6] ..., Kriya Kubar. Sekretariat Dekranasda Kabupaten Kutai Barat, Kalimantan Timur, Edisi Pertama Hut Kubar ke-17, 2016.

[7] https://diskominfo.kaltimprov.go.id/kerajinansulam-tumpar-jadi-trendsetter/

[8] Dwi Cahyadi, Etwin Fibrianie and Andi Farid H, Pengembangan Motif Sulam Tumpar Untuk Kerajinan Industri, Leutikaprio Yogyakarta. 2019.

[9] Lévy. "Beyond Kansei Engineering: The Emancipation of Kansei Design." International Journal of Design. Vol. 7 No. 2. 2013.

[10] Carole Bouchard, Alexandre Gentner, and Daniel Esquivel. "About the nature of Kansei information, from abstract to concrete." International Conference on Kansei Engineering and Emotion Research. LINKÖPING, JUNE 11-13. 2014.

[11] Punitha Turumogan, Aslina Baharum, Ismassabah Ismail , Nor Azida Mohamed Noh, Nur Shahida Ab Fatah, Noorsidi and Aizuddin Mat Noor. (2019). "Evaluating users' emotions for Kansei-based Malaysia higher learning institution website using Kansei checklist." Bulletin of Electrical Engineering and Informatics. Vol. 8, No. 1, pp. 328 335. 2019.

[12] Mehdi Aslefallah, Nasser Koleini Mamaghani, and Sina Khalkhali. "Applying Kansei Engineering method on investigating mobile phone's brand image amongst Iranian young designers." International Conference on Kansei Engineering and Emotion Research. LINKÖPING, JUNE 11-13. 2014.

[13] Alexander Radoslavov, and Alexander Nikov. "A checklist for Kansei Assessment of Food Packages." KSI Transactions on KNOWLEDGE SOCIETY. Vol. VII, No. 3. 2014.

[14] Nagamachi. Mitsuo. et al. "Innovations of Kansei Engineering.” CRC Press. 2011.

[15] A.M. Lokman. "Design \& Emotion: The Kansei Engineering Methodology", Malaysian Journal of Computing 1.1, p.1-[13] A.M.Lokman \& M. Nagamachi, Kansei Engineering - A Beginner Perspective, Malaysia: UPENA UiTM. 2010 
[16] Tharangie K G D, Irfan C M A, Yamad K and MarasingheA. "Kansei Colour Concepts to Improve Effective Colour Selection in Designing Human Computer Interfaces.” IJCSI International Journal of Computer Science Issues, Vol. 7, Issue 3, No 4. 2010 .

[17] Pierre Lévy. "Perception Theories and Kansei Design." International Conference on Kansei Engineering and Emotion Research. LINKÖPING, JUNE 11-13. 2014.

[18] Cross Nigel, Engineering Design Methods Strategies for Product Design, Fourth Edition, John Wiley and Sons Ltd, 2005.

[19] I Made Londen Batan, Desain Produk, Penerbit Guna Widya, Surabaya, 2012.

[20] Etwin Fibrianie, and Dwi Cahyadi, "Identification of Design and Development Needs for Preschoolaged Children's Educational Bags" Panggung, Vol. 27, No. 4, Dec, 2017.

[21] N. Kongprasert, D. Brissaud, C. Bouchard, A. Aoussat, and S. Butdee, "The customer-oriented bag matrix to support the design leather bags", 42nd CIRP Conference on Manufacturing Systems, Grenoble : France, 2009.

[22] Sajid Rehman Khattak, Haider Ali, Yasir Khan, and Mukharif Shah, "Color Psychology in Marketing“,Journal of Business and Tourism, Vol. 04, No.01, January - June, 2018.
[23] Christopher Lashway, Faisal Aqlan and Melanie Ford, "Ergonomic Assessment of Backpack Carriage among High School Students", Proceedings of the 2017 Industrial and Systems Engineering Conference, 2017.

[24] Hilma Raimona Zadry, Prima Fithri, Utari Triyanti and Difana Meilani, "An Ergonomic Evaluation of Mountaineering Backpacks", Journal of Engineering and Applied Sciences, Vol. 12, No. 18, Sep, 2017.

[25] Dwi Cahyadi, Etwin Fibrianie, Muh. Irwan, Hertina Susandari, and C F M Tantrika, "Design of Workstation in The Home Industry of Amplang Crackers Production", Journal of Physics: Conference Series, 2020.

[26] Seyyed Jalil Mirmohammadi, Mohammad Reza Nadri, Amir Houshang Mehrparvar, Mohammad Hossein Davari, and Mehrdad Mostaghaci, "Effect of Ergonomic Modification Training about Schoolbag on Reduction of Musculoskeletal Complaints in Primary School Students", Focus on Sciences, Vol. 2, Issue 3, Aug, 2016.

[27] Muhammad Musthofa Mubarrok, and Reni Ambarwati, "Keanekaragaman Burung di Kawasan Hutan Mangrove Banyuurip Kecamatan Ujungpangkah Kabupaten Gresik”, Jurnal Riset Biologi dan Aplikasinya, Vol. 1, No. 2, September, 2019. 